\title{
Application of the Rule of Locus Standi in Climate Change Litigations in Nigeria
}

\author{
Rita A. Ngwoke $\mathrm{PhD}^{1 *} \quad$ Rita Oguguo $\mathrm{PhD}^{2}$ \\ 1.Senior Lecturer, College of Law, Igbinedion University, Okada, Edo State, Nigeria \\ 2.Senior Magistrate, Rivers State Judiciary, Port Harcourt, Nigeria
}

\begin{abstract}
Locus Standi is a vital rule that allows for the courts or tribunals to determine who the aggrieved party is and who is an interloper. Its application to the issue of climate change in Nigeria is very strict as compared to other jurisdictions of the world. This paper examined the application of the concept in climate change litigation by Nigeria. It observed that the jurisprudence of Nigerian courts on this issue has remained overly rigid to allow for a robust legal redress for injuries caused by activities arising from majorly the oil industry, which is the prime culprit of environmental damage and greenhouse gas emissions. The paper concludes that the courts in Nigeria should adopt the liberal approach to locus standi in climate change litigation by giving premium to concerns about the impact deleterious activities on the environment and people rather than upholding rules of legal technicalities. Keywords: locus standi, jurisdiction, climate change, litigation, pollution, greenhouse gas
\end{abstract}

DOI: $10.7176 / \mathrm{JLPG} / 101-07$

Publication date:September $30^{\text {th }} 2020$

\section{Introduction}

The application of the rule of locus standi in Nigeria has its root in common law as developed in England. Under the common law, locus standi requirements differed according to the remedy sought, and the person who approaches the court for relief was required to have an interest in the subject matter of the litigation in the sense of being personally adversely affected by the alleged wrong. The plaintiff must allege that his or her rights have been infringed. It was not enough for him to allege that the defendant had infringed the rights of someone else, or that the defendant was acting contrary to the law and that it is in the public interest that the court grants relief. ${ }^{1}$ Thus, under common law, a person could only approach a court of law if he or she has sufficient, direct and personal interest in the matter. A plaintiff must in general show that he or she has some special interest or has sustained some special damage greater than that sustained by an ordinary member of the public. ${ }^{2}$

The rule of locus standi was developed primarily to protect the courts from being used as a playground by professional litigants, meddlesome interlopers and busy bodies that really have no real stake or interest in the subject matter of a suit. ${ }^{3}$ Although Nigeria did not follow the English Common Law reforms on locus standi, however, Nigerian courts substantially apply the strict legal injury or legal interest rule in determining the standing of a plaintiff to institute an action. The application of this rule is even stricter in climate change cases where the plaintiff is required to show prima facie evidence that the action of the defendant has adversely affected his right or interest in the subject matter of the claim. Indeed, the 'sufficient interest test' of the English Senior Courts Act $1981^{4}$ became adapted by way of reform into the various High Court (Civil Procedure) Rules of the different states of the Federation, ${ }^{5}$ which requires that the judge shall grant leave only if the applicant has sufficient interest in the matter to which the application relates.

This paper seeks to examine the application of the 'sufficient interest' rule in climate change litigation in Nigeria in view of the global impact of the phenomenon and its potential to affect regions and countries as a whole. We argue that the court should be more concerned about the impact on the environment and health of the ecosystem comprising the human population, fauna and the flora rather than focusing strictly on the rule of locus standi in determining climate change issues in Nigeria because of its potential to affect generations yet unborn.

\section{Conceptual Clarifications}

\subsection{Concept of Climate Change}

Climate Change is the long-term alteration of temperature and typical weather patterns in a place. ${ }^{6}$ It could refer to a particular location or the planet as a whole or may cause weather patterns to be less predictable. These

\footnotetext{
${ }^{1}$ Oyelowo Oyewo, 'Locus Standi and Administrative Law in Nigeria: Need for Clarity of Approach by the Courts' (2016) 3(1) International Journal of Scientific Research and Innovative Technology, 79-80

${ }^{2}$ Ibid.

${ }^{3}$ See Taiwo v. Adegboro [2011] 11 NWLR (Pt. 1259) 562 at 579, Per Rhodes-Vivour JSC (SC).

${ }^{4}$ See section 31(3) of the Act.

${ }^{5}$ See e.g. Order 40 r. 3(4) of the High Court of Lagos State (Civil Procedure) Rules 2012. Fidelis Nwadialo, Civil Procedure in Nigeria, 2nd edition (University of Lagos Press, 2000) 31-44,.

${ }^{6}$ National Geographic, 'Climate Change' available at: <https://www.nationalgeographic.org/> accessed $10^{\text {th }}$ June 2020.
} 
unexpected weather patterns can make it difficult to maintain and grow crops in regions that rely on farming because expected temperature and rainfall levels can no longer be relied on. It is also connected with other damaging weather events such as more frequent and intense floods, downpours, and winter storms. Climate change is defined as a broad range of global phenomena created predominantly by burning fossil fuels, which add heattrapping gases to the Earth's atmosphere. ${ }^{1}$ These phenomena include the increased temperature trends described by global warming, but also encompass changes such as sea level rise, ice mass loss in Greenland, Antarctica, the Arctic and mountain glaciers worldwide, shifts in flower/plant blooming, and extreme weather events.

It has also been connected with other damaging weather events such as frequent and more intense hurricanes, floods, downpours, and winter storms. The cause of the current climate change is largely human activity, like burning fossil fuels, large-scale farming and pollution arising from industrial activities. These activities release greenhouse gases into the earth's atmosphere, which trap heat from the sun's rays inside the atmosphere causing the earth's average temperature to rise. The warming of the planet affects local and regional climates.

\subsection{Concept of Locus Standi}

The word 'locus' (plural loci) is the Latin word for 'place'; locus standi therefore, means 'place to stand'. In the legal parlance, this means the right to bring an action - the ability of a party to demonstrate to the court sufficient connection to the subject matter of the claim to support that party's participation in the case. ${ }^{2}$ According to the US case of Warth v. Seldin, "the question of standing [involves] whether the litigant is entitled to have the court decide the merits of the dispute or of the particular issues". Consequently, there are three constitutional standing requirements of the rule of locus standi: ${ }^{4}$

a) Injury: The plaintiff must have suffered or imminently will suffer injury - an invasion of a legally protected interest which is concrete and particularized. The injury must be actual or imminent, distinct and palpable, not abstract. This injury could be economic as well as non-economic or both; ${ }^{5}$

b) Causation: There must be a causal connection between the injury and the conduct complained of, so that the injury is fairly traceable to the challenged action of the defendant and not the result of the independent action of some third party who is not before the court; ${ }^{6}$ and

c) Redress ability: It must be likely, as opposed to merely speculative, that a favorable court decision will redress the injury. ${ }^{7}$

Furthermore, Locus standi generally means the legal capacity to institute proceedings in a court of law. ${ }^{8}$ It is sometimes used interchangeably with the terms "standing" or "title to sue". It has been defined as the right of a party to appear and be heard on the question before any court or tribunal. ${ }^{9}$ The Black's Law Dictionary, ${ }^{10}$ defines it as a Latin word meaning "place of standing - the right to bring an action or to be heard in a given forum".

Also, the Nigerian Supreme Court, in a brief but succinct manner stated the meaning of locus standing in the case of Chidi Nworika v. Mrs. Ann Ononeze-Madu \& Ors ${ }^{11}$ as follows; "however, beyond analogical inferences or conjectures, the issue of locus standi is the actual legal capacity of instituting or commencing an action in a competent Court of law without inhibition, obstruction or hindrance from any person or body whatsoever".

\footnotetext{
${ }^{1}$ WIRED, 'What is Climate Change? The Definition, Causes and Effects' (2018) available at: https://www.wired.co.uk/article/what-is-climatechange-definition-causes-effects $>$ accessed $10^{\text {th }}$ June 2020 .

${ }^{2}$ Law Web, 'Unique Legal Database', available at: < https://www.lawweb.in/2015/02/basic-concept-of-locus-standi.html $>$ accessed $2^{\text {nd }}$ June 2020.

${ }^{3}$ (1975 ) 422 S.C. 490, was a United States Supreme Court case in which the Court reviewed the concept of judicial standing and affirmed that if the plaintiffs lacked standing, they could not maintain a case against the defendants. Also the Court found that as none of the plaintiffs could demonstrate any injury actually done to them by the defendants, the plaintiffs were third parties to the issue and had no standing to sue. The plaintiff's descriptions of their own meager financial situations and subsequent inability to live in Penfield were found by the Court to be the consequence of the economics and housing market of the area rather than any wrongdoing by the defendants. See Wikipedia, 'Standing' (Law), available at: $<$ https://en.wikipedia.org/wiki/Standing_(law)\#cite_note-37>accessed $5^{\text {th }}$ June 2020.

${ }^{4}$ Ibid.

${ }^{5}$ Varma Corey, 'The Presumption of Injury: Giving Data Breach Victims a Leg To Stand On', (2016) 4 Journal of Information Technology \& Privacy Law 32.

${ }^{6}$ For example, Massachusetts v. Environmental Protection Agency (global warming caused by EPA's refusal to regulate carbon dioxide emissions satisfied element of causation for Massachusetts's alleged injury of loss of coastland).

${ }^{7}$ Lujan v. Defenders of Wildlife, 504 U.S. 555 (1992), was a United States Supreme Court case decided on June 12, 1992, in which the court held that a group of American wildlife conservation and other environmental organizations lacked standing to challenge regulations jointly issued by the U.S. Secretaries of the Interior and Commerce, regarding the geographic area to which a particular section of the Endangered Species Act of 1973 applied. The case arose over issues of US funding of development projects in Aswan, Egypt and Mahaweli, Sri Lanka that could harm endangered species in the affected areas. The government declared that the act did not apply to projects outside of the United States and Defenders of Wildlife sued.

${ }^{8}$ Senator Adesanya v. President of the Federal Republic of Nigeria (1981) 5 SC. 112.

${ }^{9}$ Ogunsanya v. Dada (1992) 4 SCNJ 162.

${ }^{10}$ Bryan A. Garner (ed.), Black's Law Dictionary, $9^{\text {th }}$ ed. 1999, 1026.

${ }^{11}$ Legalpedia Electronic Citation: LER [2019] SC.307/2008. See also the cases of Inakoju v Adeleke (2007) All FWLR (Pt.353) 1 at 96; Thomas v Olufosoye (1986) 2 SC 325, Momoh v. Jimo Olotu (1979) All NLR 117, at 123, A.G. Anambra v. Eboh (supra) PER S.D.BAGE, J.S.C.
} 


\section{Nature of Locus Standi in Nigeria}

Judicial parameters of locus standi have been set in the case of Abacha \& Anor v. AG Federation ${ }^{1}$ where the court pronounced on the nature of locus standi citing the case of Nyame $v$ Federal Republic of Nigeria ${ }^{2}$ and held that the term locus standi entails the legal capacity of instituting, initiating or commencing an action in a competent court of law or tribunal without any inhibition, obstruction or hindrance from anybody or person whatsoever including the provision of any existing law. ${ }^{3}$

The fundamental aspect of locus standi is that it focuses on the party seeking to get its complaint heard before the court. Also, it is settled law that the plaintiff will have locus standi in a matter only if he has special right or alternatively, if he can show that he has sufficient or special interest in the performance of the duty sought to be enforced or where the interest is adversely affected.

In addition, locus standi is a condition precedent to instituting an action before a court of law. ${ }^{4}$ It is a legal voice with which the plaintiff amplifies his legal rights over and above those of ordinary men. The issue of locus standi constitutes a condition precedent to the institution of any action before a court of law. For an action to be maintainable, the person instituting it must have legal capacity, otherwise the court is robbed of necessary jurisdiction to entertain it. Whenever the issue of locus standi is raised, the court before which the action is pending is under a duty to determine it first before going into the merit of the action itself. ${ }^{5}$ Also, the court further extended the frontiers of locus standi to the effect that a "general interest common to all members of the public is not a litigable interest to allow standing and that a citizen, without more, has no locus". 6

The rule of locus standi is a basic prerequisite for the invocation of the jurisdiction of the court because it is the authority given by law to a court or tribunal to try cases and rule on legal matters within a particular geographic area and/or over certain types of legal cases. It is vital to determine before a lawsuit is filed which court has jurisdiction. Thus, like the issue of jurisdiction, locus standi is also a threshold issue. ${ }^{7}$ That the plaintiff has locus standi to institute an action is a condition precedent to the court's jurisdiction. In other words, where the party initiating an action lacks locus standi, the court is robbed of jurisdiction to hear that matter. ${ }^{8}$ The rule of locus standi applies both in criminal and civil proceedings. Section 6(6)(c) of the Constitution of the Federal Republic of Nigeria (as amended) clearly underlines the importance of locus standi in civil proceeding wherein it provided that the "judicial power vested in the courts established under the constitution shall extend to all matters between persons, or between government or authority and any person in Nigeria, and all actions and proceedings related thereto, for the determination of any question as to the civil rights and obligations of that person".

In the case of Tony Anozia v. The Attorney General, Lagos State locus standi was held to denote the right of a party to institute an action in a court of law or seek judicial enforcement of a duty or right. Just like any other case, the first issue that needs to be contended with in instituting climate change litigation is who can sue and who should be sued, in other words who are the proper parties to climate change suit. It is trite law that for a suit to be proper before a court or tribunal the proper parties must be the ones in court.

\section{Locus Standi in Climate Change Cases in Nigeria}

In Nigeria, the rule on who a proper party is, especially as it relates to the institution of climate change matters is very strict. The plaintiff in an action must prove that he has the locus to institute the action. To have locus standi to institute an action in a court or tribunal the plaintiff must establish the following:

a) That the act being challenged has caused the plaintiff actual injury; and

b) That the interest sought to be protected is within the zone of interests meant to be regulated by the statutory or constitutional guarantee in question. ${ }^{10}$

Furthermore, the two main tests for determining whether a party has special and sufficient interest in instituting an action are: (a) whether the plaintiff could have been joined as a party to the suit if some other party commenced the action; and (b) whether the plaintiff will suffer some hardship or injury arising from the litigation

\footnotetext{
${ }^{1}$ Abacha \& Anor v. AG Federation \& Ors. (2013) LPELR-21479.

2 (2010) 42 NSCQR 54

${ }^{3}$ Ibid.

${ }^{4}$ Legalpedia Electronic Citation: LER [2019] SC.307/2008, available at: < https://legalpediaonline.com/chidi-b-nworika-vs-mrs-ann-ononezemadu-ors/> assessed $2^{\text {nd }}$ June 2020.

${ }^{5}<\mathrm{https}$ ://legalpediaonline.com/chidi-b-nworika-vs-mrs-ann-ononeze-madu-ors/ >assessed $2^{\text {nd }}$ June 2020

${ }^{6}$ See the case of A.G. Federation v. Abubakar (2007) 10 NWLR (Pt.1 041) 1 at 75, Adewunmi v. Ogebelle (1983) 4 WCLR (Vol.4) 662 at 677.

Per S.D. Bage, J.S.C in the case of AG Federation v. Abubakar (supra).

${ }^{7}$ Niki Tobi, 'Judicial Enforcement of Environmental Laws in Nigeria', (2002) 2 Journal of Environmental \& Planning Law 91; Also His PreEminence Boliaji v. Rev. Bamgbose (1986) 4 NWLR (Pt. 37) 632.

${ }^{8}$ Legalpedia Electronic Citation: LER [2019] SC.307/2008, available at: < https://legalpediaonline.com/chidi-b-nworika-vs-mrs-ann-ononezemadu-ors $>$ assessed $3^{\text {rd }}$ June 2020, See also the cases of Charles v. Gov. Ondo State (supra), Inakoju v. Adeleke (2007) 4NWLR (Pt. 1025) 423; Yesufu v. Govt. Edo State (2001) 13 NWLR (Pt. 731) 517; Adesanya v President, F.R.N (1981)2 NCLR 358.

${ }^{9}$ (2012) All FWLR (Pt. 631) 1522.

${ }^{10}$ Tony Anozia v. The Attorney General, Lagos State (supra)
} 
if some other person instituted the action. ${ }^{1}$

Because climate change litigation generally involves a large group of persons under class action, this type of litigation is particularly difficult to commence in Nigeria due to the stringent and rigid rules of initiating such actions. As a result, no case directly on climate change has yet been successfully litigated in Nigeria, even as only few of such cases have been prosecuted in other countries. This is notwithstanding the fact that people, communities and groups all around the globe especially in Nigeria suffer huge damages or trauma directly or indirectly as a result of the impact of climate change. ${ }^{2}$ While these impacts are more enormous on the lives and livelihoods of the poorer segments in societies, especially in developing countries, the culprits are concentrated in the developed world who rely almost wholly on fossil fuel to drive the wheel of industrialization. Although, Nigeria and other developing countries also feature prominently in the rising climate change index due to the heavy load of gas flaring and emissions arising from the oil industry, climate change litigation is yet to firmly take root in our legal system. ${ }^{3}$

However, the likely parties to climate change litigation would be individuals, communities or regions impacted directly by the consequences of climate change. On the other hand, the defendant most likely will constitute the oil companies, government and their agencies and even countries in international cases. Notwithstanding, Sampson and Kaiser opines that since climate change is a global problem, litigating it in the future may likely encompass whole populations as plaintiffs or defendants. ${ }^{4}$ Conversely, in all civil matters affecting a segment of the society, the courts in Nigeria have always insisted that the plaintiff must show evidence that he has suffered a wrong. Accordingly, a plaintiff who sues for damages arising from an environmental abuse or climate change must show that he suffered damages. This position was applied in the case of Shell Petroleum Development Company of Nigeria v. Chief Otoko \& Others. ${ }^{5}$ In this case, the respondents who were plaintiffs at the Bori High Court in Rivers State were members of different communities surrounding the Andoni River and creeks and they brought this action in a representative capacity. They claimed $\$ 4,499,855.00$ being compensation payable by the defendant for injurious affection to and deprivation of the use of the Andoni River and creeks as a result of the spillage of crude oil caused by the negligence of the defendant. In addition, there was an oil spillage in the manifold along the eastern coastal Truck pipeline between Muma and Oyorokoto on the $6^{\text {th }}$ of October 1981, but came to the knowledge of the defendant (appellant) on the $7^{\text {th }}$ of October 1981. The spillage polluted the Andoni River and creeks with resultant damage to the properties of the plaintiff/respondent and the economic life of the communities, which was mainly fishing was brought to a standstill. The appellant however on learning of the spillage went to the area of the spill and stopped the leakage in the manifold.

At the trial court, the Judge found for the plaintiff and awarded damages against the defendant. Being dissatisfied, the defendant appealed to the Court of Appeal wherein it raised the issue of locus standi and contended that the suit was wrongly constituted by reason of misjoinder of parties. The Court of Appeal upholding the submission of the respondent held that it is essential that the persons who are to be represented and those representing them to have the same interest in the cause of action. ${ }^{6}$ The court per Omosun (JCA), delivering the lead judgment, stated that the respondents are six different communities not six villages in one community, and that there was a diversity of interests for the damage caused to each of them to which the claim can only be personal to each of them. The court further stated that given a common interest and common grievance, a representative suit would be in order if in addition to the relief sought, the action is beneficial to all whom the plaintiff proposes to represent. The court rejected the purported representative action.

With the great respect to the judges in this case, we beg to disagree with them in their conclusion. Even if the suit for representative capacity should failed, why did the court not award damages to the respective communities for the injuries they suffered separately even when the defendant accepted that there was oil spillage? The court did not award anything for the injuries suffered by the plaintiff. Indeed, in the latter case of Adediran v. Interland Transport $L t d^{7}$ the Supreme Court shifted its position and gave the requirement for suing in a representative capacity as follows:

(a) There must be a common interest;

(b) There must be a common grievance; and

(c) The relief claimed must be beneficial to all.

\footnotetext{
1 'K'Line Inc v. K. R. International (Nig.) Ltd (1993) 5 NWLR (Pt. 292) 159 and Anozie v. A. G. Lagos State (supra) 1526.

2 Okorodudu-Fubara, 'Climate Change: Issues in Law and Governance', (2012) 7.

${ }^{3}$ Ibid.

4 B. Sampson and S. Kaiser 'Climate Change Litigation - How Soon is Now', (2011), available at: $<$ http://whoswholegal.com/nows/features/articles/29096/climatechangelitigation-soon-now >accessed $13^{\text {th }}$ May 2020.

5 (1990) 6 NWLR (Pt. 159) 693.

${ }^{6}$ This decision of the Court of Appeal was made after reference to Order 4 Rule 3 of the High Court Rules Eastern Nigeria Cap 61 applicable to the proceeding then. The said provision provides that "where more persons than one have the same interest in one suit, one or more of such persons may with the approval of the court be authorized by the other persons interested to sue or to defend in such suit for the benefit of or on behalf of all parties interested". See also Oragbade v. Oniliju (1962) 1 All N.L.R. 32.

${ }^{7}$ (1986) 2 NWLR (Pt. 20) 78.
} 
Thus, where there is nothing in the pleadings or on the evidence to show that each of the persons represented have a common interest in the matter, the court will not entertain the suit if it is brought on representative capacity. It is pertinent to say that a perusal of most oil and gas pollution litigation reveals that they are usually brought in representative capacity. This is due to the fact that the impact of oil and gas exploration like gas flaring which is acclaimed to cause climate change in a particular locality affects virtually all inhabitants of the locality even though in diverse forms. The court in Adediran's case $e^{1}$ held that where different torts or injuries arise from the same nuisance complained of, and claimed in the same action, each separate injury constitutes a distinct tort actionable at the instance of the person who has suffered it. Onyeabo, ${ }^{2}$ had cause to comment on the situation when he said;

The fundamental aspect of locus standi is that it focuses on the party seeking to get his complaint before the court and not in the issue he wishes to have adjudicated. Thus, the concept of locus standi concerns the capacity of a person to institute legal proceeding in a court of law or other competent tribunal.

A typical instance of where the court has used the issue of locus standi to dismiss a suit on oil and gas affecting the environment is the case of Warri North Local Government Area of Delta State of Nigeria v. Mobil Producing Nigeria Limited. ${ }^{3}$ In this case, following a massive oil spillage around Idono Platform, Qua Iboe terminal of Mobil Producing Nigeria Unlimited on January 12, 1998, three communities of Warri separately instituted suit against Mobil claiming $\$ 994,125,426$ as damage. ${ }^{4}$ The three groups jointly claimed that their only means of livelihood, which was fishing was destroyed as a result of the pollution which occurred on January 12, 1998 from a busted pipe carrying crude oil from the Idoho platform Qua Iboe terminal, belonging to Mobil. The plaintiffs pleaded that they commissioned an environmental firm and surveyor cum valuer who prepared a Comprehensive Environmental Impact Assessment Report in respect of the damages suffered by them. Mobil, the defendant denied the entire allegation saying that at all material times, it carried out its operations in strict compliance with the regulations of the Department of Petroleum Resources (DPR). Mobil admitted only that an oil spill occurred offshore of the coast of Akwa Ibom State and that it immediately notified all the appropriate Federal and State authorities including DPR, Federal Environmental Protection Agency (FEPA) and other environmental protection agencies in operation then. Mobil described the plaintiff's environmental test as 'non-scientific' as it only included inspection of beaches and river mouths and banks, towns and villages, water systems, soil and sediment for sign of petroleum hydrocarbons to be matched against Mobil's Idoho light crude in order to attribute it to the Mobil oil spill incidence. Mobil therefore asked the court to dismiss the plaintiff's claim with substantial cost, same being "frivolous, speculative and an abuse of the process of the court". The learned justice Anta J. of the Federal High Court Benin then, in his judgment suo motu raised the issue of the locus standi of the plaintiffs in instituting the action. As he held, "It is pertinent to note that for an action to lie in a representative capacity there must be a common interest, there must be a common grievance and the relief claimed must be beneficial to all". In his ruling, the learned judge went ahead to hold that:

In this case, it is clear and not in doubt that the case or complain as is common to the community is that the oil spillage affected the economic activities of the people in the area. But from the evidence before this court, the wrong suffered by the parties are not the same and are not common. The extents of damage claimed are also different. It is the position of the law that the case of each community must depend on its own merit, as the cause of action are different. There is no common interest or grievance for the plaintiff to sue in a representative capacity.

The plaintiff's case therefore failed and was accordingly dismissed. It is worthy of mention that in its ruling above, the court sadly focused on the parties rather than the damages done to the people and the environment generally. Even when the defendant Mobil, did not deny the fact that there was oil spillage, which most have wrecked damage on both the environment and people. There is need for a departure from such position because in other jurisdictions where locus standi is equally a fundamental issue in trials on climate change, there is the consciousness of focusing on the damage to individual and environment rather than technicalities as done in Nigeria. Nigeria should conform to prevailing international best practices and legal sentiments on the care for the environment and the injuries suffered by the people.

In the US case of Friends of the Earth Inc. \& Ors. v. Watson Peter \& Philip Merill,,$^{5}$ the plaintiff claimed that the defendant in their official capacity as Chief Executive Officers and Vice President of the Oversea Private Investment Corporation (OPIC) and the Export-Import Bank of the United States (Ex-Im) respectively failed to comply with the National Environmental Policy Act 1969 (NEPA). ${ }^{6}$ The Act requires that all federal agencies

\footnotetext{
${ }^{1}$ Ibid.

${ }^{2}$ E. U. Onyeabo, 'Institutional Framework for Environmental Protection: The Judiciary, Its Role and Witnesses', (2004) 11

${ }^{3}$ Guardian Newspaper - Monday April 11, 2005.

${ }^{4}$ The 1st suit was 127 fishermen of the Ogheye Eghoroke and Ogheye Dimigun sea-side community of Ogheye, Beni River asking for N633,472, 431 for damages while another 71 fishermen of Barrentie community and Benin River claimed for N46,797,060 and the $3^{\text {rd }}$ suit from the seaside community claimed $\mathrm{N} 313,655,935$. The three claims were consolidated.

52005 WL 2035596, 35 Environmental Law Report, 20. P. 179 or U.S. Court of Appeals for the Ninth Circuit - 518 F.2d 323 (9th Cir. 1975).

6 Section 102-103 of the U. N. National Environmental Policy Act 1969, 42 U.S.C. $\S 4321$ et seq. available at:
} 
conduct an environmental review of all programs and projects that could have a significant effect on the environment, and the plaintiff contended OPIC and Ex-Im provided financial support to fossil fuel projects abroad, which resulted in the release of large quantity of greenhouse gas emission, which has significant impact on human environment. They therefore sought a declaratory and injunctive relief against the defendants. But the defendants brought a motion to dismiss the suit on the grounds that inter alia, the plaintiffs lack the standing to institute the action.

The U.S Northern District Court of California, San Francisco division holding that the plaintiff had locus standi to bring the action stated that to prove standing, a plaintiff must show:

a) It has suffered an injury in fact that is (i) concrete and particularized and (ii) actual or imminent, not conjectural or hypothetical;

b) That the injury is fairly traceable to the challenged action of the defendant; and

c) It is likely as opposed to merely speculative that the injury will be redressed by a favorable decision.

The court further held that to demonstrate standing in cases raising procedural environmental issues, the plaintiff need not show that substantive environmental harm is imminent, but that the plaintiff can show that it was reasonably probable that the challenged action would threaten their concrete interests. In the court's opinion, the plaintiff's evidence that increased greenhouse gases is a major factor that causes global warming; that global warming has in fact, started occurring and continued emission of greenhouse gases would continuously increase global warming with various environmental impacts which affect even areas used and owned by the plaintiff was sufficient evidence to demonstrate the plaintiff's concrete interest. ${ }^{1}$ This is a far liberal view than what obtains in Nigeria. The focus here unlike in Nigeria is whether indeed there is probable harm to the class of persons even though in different ways and whether the action of the defendant is likely responsible.

Similarly, in the case of Centre for Biological Diversity, Blue Water Network and Sierra Club v. Spencer Abraham $^{2}$ which also came up in the US Northern District Court of California in 2002, the issue of locus standi to sue in the matter, which had bearing on climate, change came up. The plaintiff had filed a complaint with the court alleging that the defendants had failed to comply with the Energy Policy Act provisions of the acquisition of Alternative Fuel Vehicles (AFVs). The defendant on the other hand though had agreed that the government did not comply, raised an objection to the standing of the plaintiff contending the plaintiff lacked standing to institute the action because they had not identified any concrete and particularized injuries caused by the government's conduct and redressable through judicial intervention. The court following its ruling in the Friends of Earth case ${ }^{3}$ upheld the locus standi of the plaintiff holding that an association (like the plaintiff) has the standing to sue on behalf of its members where the members would otherwise have the standing to sue in their own right. That the interests at stake were germane to the organization's purpose and the claim did not assert nor does the relief claimed to require the participation of individual members in the lawsuit.

The plaintiffs also claimed that they had experienced or were experiencing injuries relevant to establishing standing through, inter alia, (1) concerns regarding the adverse health effects of smog and air pollution caused by vehicle emissions; (2) concerns about and assertions regarding global warming; (3) traffic complaints; and (4) aesthetic injuries. ${ }^{4}$ The Court however, held that some of these injuries were not sufficient to demonstrate standing. First, it was unclear to the court how 'traffic problems' would be eased by an injunction that would require defendants to buy cars running on alternative fuels rather than gasoline. ${ }^{5}$ Second, the court found that the concerns regarding global warming were "too general, too unsubstantiated, too unlikely to be caused by defendants' conduct, and/or too unlikely to be redressed by the relief sought to confer standing". 6

Notwithstanding, although the court rejected standing on grounds of general concern for global warming, it still recognized standing on the bases of aesthetic injuries caused by greenhouse gas emission and adverse health effect of smog and air pollutants which are also linked to climate change.

\section{Conclusion}

Conclusively, without any fear of contradiction, it is the position of the writers that the issue of locus standi is paramount in climate change litigation and it runs across all countries of the world. However, the jurisprudence of class action in Nigeria remains an obstacle to effective climate change litigation, as conditions set by the courts appear too rigid to encourage successful litigation against oil companies who are the major culprits of

$<$ http://www.nepa.gw/regs/nepa/nepaegia.htm> accessed $11^{\text {th }}$ May 2020.

${ }^{1}$ See Center for Biological Diversity v. Abraham, 218 F.Supp.2d 1143 (N.D.Cal. Jul 30, 2002) (NO. 3:02CV00027). Also, the court's ruling in this area was based on the citizens for Better Forestry, $9^{\text {th }} 2004$ wherein government agency violated certain procedural rules and that these rules protect a plaintiff concrete interest.

2218 F.Supp.2d 1143 (N.D.Cal. Jul 30, 2002) (NO. 3:02CV00027).

3 (2005) WL 2035596, 35 ENVTL. L. REP. 20,179 (N.D. Cal. Aug 23, 2005) (NO. C 02-4106 JSW).

${ }^{4}$ Amsterdam International Law Clinic and Michael G. Faure \& André Nolkaemper, 'Analyses of Issues to be Addressed Climate Change Litigation Cases', Friends of the Earth Netherlands - Milieudefensie, (2007) 10.

${ }^{5}$ Ibid.

${ }^{6}$ Ibid. 
environmental damage and atmospheric pollution. The courts in Nigeria must adopt a more liberal approach to locus standi in environmental and climate change suits brought before them, which must conform to prevailing international best practices and legal sentiments on care for the environment and peoples above legal technicalities.

\section{References}

Corey, V. (2016). "The Presumption of Injury: Giving Data Breach Victims a Leg To Stand On”. 4 Journal of Information Technology \& Privacy Law 21-39.

Garner, B.A. (ed.), (1999). Black's Law Dictionary. $9^{\text {th }}$ ed.

Law Web. "Unique Legal Database". Available at: < https://www.lawweb.in/2015/02/basic-concept-of-locusstandi.html $>$ accessed $2^{\text {nd }}$ June 2020

National Geographic. "Climate Change". Available at: $<$ https://www.nationalgeographic.org/ $>$ accessed $10^{\text {th }}$ June 2020.

Nwadialo, F. (2000). Civil Procedure in Nigeria, 2nd ed. (University of Lagos Press).

Oyewo, O. (2016). "Locus Standi and Administrative Law in Nigeria: Need for Clarity of Approach by the Courts". 3(1) International Journal of Scientific Research and Innovative Technology, 65-89.

Sampson, B. and Kaiser, S. (2011). "Climate Change Litigation - How Soon is Now". Available at: $<$ http://whoswholegal.com/nows/features/articles/29096/climatechangelitigation-soon-now $>$ accessed $13^{\text {th }}$ May 2020.

Tobi, N. (2002). "Judicial Enforcement of Environmental Laws in Nigeria', 2 Journal of Environmental \& Planning Law 83-97.

WIRED. (2018). "What is Climate Change? The Definition, Causes and Effects". Available at: https://www.wired.co.uk/article/what-is-climate-change-definition-causes-effects $>$ accessed $10^{\text {th }}$ June 2020.

A.G. Federation v. Abubakar (2007) 10 NWLR (Pt.1 041) 1.

Abacha \& Anor v. A.G. Federation \& Ors. (2013) LPELR-21479.

Adewunmi v. Ogebelle (1983) 4 WCLR (Vol.4) 662.

Center for Biological Diversity v. Abraham, 218 F.Supp.2d 1143 (N.D. Cal. Jul 30, 2002) (NO. 3:02CV00027).

His Pre-Eminence Boliaji v. Rev. Bamgbose (1986) 4 NWLR (Pt. 37) 632.

Inakoju v. Adeleke (2007) 4NWLR (Pt. 1025) 423.

Lujan v. Defenders of Wildlife, 504 U.S. 555 (1992).

Momoh v. Jimo Olotu (1979) All NLR 117, at 123.

Ogunsanya v. Dada (1992) 4 SCNJ 162.

Senator Adesanya v. President of the Federal Republic of Nigeria (1981) 5 SC. 112.

Taiwo v. Adegboro [2011] 11 NWLR (Pt. 1259) 562.

Thomas $v$ Olufosoye (1986) 2 SC 325.

Yesufu v. Govt. Edo State (2001) 13 NWLR (Pt. 731) 517.

High Court of Lagos State (Civil Procedure) Rules 2012. 